\title{
PARLIAMENTARY, MINISTERIAL, AND JUDICIAL CONTROL OF NATIONALIZED INDUSTRIES IN GREAT BRITAIN
}

\author{
Charles Winter*
}

In establishing a series of public business corporations, care has been taken to allot them a suitable status in the constitution and in fixing that status a carefully adjusted system of controls has been devised. These controls have been established in relation (a) to Parliament which is responsible for the creation of the particular corporation; (b) to the minister designated by Parliament as ultimately answerable to Parliament for the working of the corporation; and (c) to the judiciary in connection with its task of interpreting and enforcing the law of the land.

Parliamentary Control

A. The Creating Statute

The first opportunity for determining the extent of parliamentary control over a public corporation occurs in the consideration of the bill which when passed by Parliament becomes the creating statute defining the scope of the activities entrusted to the public corporation whether as a body with paramount power (such as the National Coal Board), or as a central body aided by ancillary area organizations (such as the British Transport Commission with its six Executives responsible for railways, docks, and inland waterways, road passenger transport, road haulage, hotels, and London transport; the British Electricity Authority with its fourteen area boards; and the Gas Council with its twelve area boards), or as a central body holding the securities of subsidiary publicly owned companies (such as the Iron and Steel Corporation). The usual stages in the preparation of a bill are the formulation of instructions by the state department concerned for submission to the parliamentary counsel who drafts the bill which is introduced in the House of Commons by the responsible minister. In its passage through that House and subsequently through the second chamber, the House of Lords, there is opportunity for discussion by the members of those Houses and they share the responsibility for fixing the scope of the activities of the corporation set up to control the particular business or industry and the powers of any subsidiary corporations needed for that purpose.

* LL.M. (London), of Gray's Inn, Barrister-at-law, Member of the Council of the Institute of Public Administration and Chairman of the Publications Committee of the Institute. Author, CHILDREN AND Young Persons Under the Law (London, 1949); The Adoptton Act 1950, Annotated (London, 1951). This article is part of the relevant chapters of the author's book on Pablic Business Corporations, now in course of preparation. It is included in this symposium by the kind permission of the publishers, Stevens and Sons, Ltd., London. 
An examination of the Coal Industry Nationalisation Act, $1946,{ }^{1}$ which may be regarded as the model for the creation of a public business corporation, reveals the main principles applied by Parliament for the control of the corporation. Under that Act the National Coal Board is established and its main duties are defined, namely, to work and get coal in Great Britain, to secure the efficient development of the coal-mining industry, and to make supplies of coal available in such qualities and quantities and at such prices as are best calculated to further the public interest. The Board is also to secure the safety, health, and welfare of its employees and utilize their practical knowledge and experience in the organization and conduct of operations; and to balance revenues against outgoings on an average of good and bad years.

The powers of the responsible minister (the Minister of Fuel and Power) in relation to the Board are carefully defined. He is to give the Board directions of a general character as to the exercise of its functions in matters appearing to him to affect the national interest. The Board in framing programs of reorganization or development involving substantial outlay on capital account and in exercising its functions as to training, education, and research is to act on lines settled with the approval of the Minister. The Board is to furnish the Minister with information (including returns and accounts) required by him with respect to the property and activities of the Board.

Consumers' councils are set up and provision is made for the consideration of their reports by the Minister. The Minister is empowered to give the Board directions for the remedying of defects notified to him by the councils. The councils are to make annual reports to the Minister and their reports are to be laid before Parliament.

The transfer of assets to the Board and the payment of compensation therefor is carefully regulated. Financial provisions deal with advances by the Minister to the Board, the borrowing powers of the Board, the establishment of a reserve fund, the keeping and auditing of accounts, and the issue of stock.

The Board is to establish machinery for the settlement of the terms and conditions of employment of its employees. It is not to be exempt from taxation. It is to make an annual report to the Minister and he is to lay the report before Parliament.

Further considerations arise in connection with later statutes affecting other industries. One important feature is the establishment of ancillary area organizations with separate corporate existence to work in conjunction with the central body. Thus, under the Transport Act, $1947,{ }^{2}$ Section 5, public authorities known as Executives are authorized to assist the British Transport Commission in the discharge of its functions. Six Executives have been appointed under this authority; viz., the Railway Executive, the Docks and Inland Waterways Executive, the Road Passenger Transport Executive, the Road Haulage Executive, the London Transport

\footnotetext{
19 \& Io GEO. 6, c. 59 .
}

$=10$ \& 12 GEO. 6, c. 49 . 
Executive, and the Hotels Executive. Under the Electricity Act, $1947{ }^{3}$ Section I, fourteen Area Electricity Boards have been set up to deal with the distribution of electricity supplies under the Central Electricity Authority which is responsible mainly for the generation of the electricity supply. Under the Gas Act, $1948{ }^{4}{ }^{4}$ twelve Area Gas Boards are the dominating authorities for the supply of gas in their respective areas and they are assisted by the Gas Council which acts as a co-ordinating authority. Under the Iron and Steel Act, I949, ${ }^{5}$ the Iron and Steel Corporation functions as a company holding the securities of some ninety-six subsidiary companies engaged in working iron ore and producing steel.

The interests of consumers are protected in the case of transport by the establishment of a Central Transport Consultative Committee for Great Britain and by Transport Users Consultative Committees set up for such areas as the Minister of Transport may direct. ${ }^{6}$ In the case of electricity and gas, a Consultative Council is established for each of the subsidiary areas. ${ }^{7}$ For iron and steel, there is set up the Iron and Steel Consumers' Council, which is empowered to appoint committees to consider matters affecting the interests of particular classes of consumers. ${ }^{8}$

The compilation and review of charges schemes assumes particular importance in the case of the transport industry and a special tribunal-the Transport Tribunalhas been created to deal with that subject. ${ }^{9}$ In regard to electricity, the scope of the manufacturing powers of the British Electricity Authority in respect of electrical plant and fittings is limited to supplies for the home market, ${ }^{10}$ and the obligation to supply electricity to railways for purposes of haulage or traction is made a responsibility of the Authority and is subject to ministerial regulations fixing the terms and conditions of that supply. ${ }^{11}$ As regards transport, restrictions are placed on the carriage of goods for hire or reward otherwise than by the British Transport Commission. This particularly affects holders of $\mathrm{A}$ or $\mathrm{B}$ licenses ${ }^{12}$ who need a permit from the Commission if their vehicles operate at a distance of more than 25 miles from their respective operating centers. ${ }^{13}$ In respect of iron and steel, persons engaged in iron or steel production, their businesses not having been acquired by the Iron and Steel Corporation, are (with exceptions for businesses already in existence on November 24, 1949) not allowed to carry on their activities without a license from the Minister of Supply if their annual production amounts to 5,000 tons or more. ${ }^{14}$ In the case of the new development of carbonization, provision is made for consultation between the various bodies affected, viz., the National Coal Board, the Gas Council, the Area Gas Boards, and the Iron and Steel Corporation. ${ }^{15}$

\footnotetext{
3 Io \& II GEo. 6, c. 54 .

'Transport Act, 1947, $\$ 6$.

"II \& I2 GEo. 6, c. 67. 5 I2 \& 13 GEo. 6, c. 72.

${ }^{8}$ Iron and Steel Act, 1949, \$6.

"Electricity Act, 1947, \$7; Gas Act, 1948, \$9.

III. $\$ 49$.

${ }^{12}$ Holders of A licenses carry goods of other persons, and holders of $B$ licenses carry their own goods as well as those of other persons.

${ }^{13}$ Transport Act, I947, $\$ \$ 52-55$.

${ }^{15}$ See Gas Act, 1948, \$\$8 and 51; Iron and Steel Act, 1949, \$47.
} 
The control exercised in relation to the bill for the creating statute takes the form of amendments to the bill moved either by or on behalf of the minister concerned as a result of criticism expressed in debate or sometimes secured by a vote of the House of Commons or the House of Lords in spite of the attitude of the minister. Where strong views are expressed by members of either House, the minister frequently makes concessions in order to secure the passage of the bill, and Parliament as a whole thus takes responsibility for framing the general policy in regard to the scope of the activities allotted to the corporations brought into being by the creating statute.

\section{B. Consideration of Annual Reports of Corporations}

The standard provision as regards annual reports of public business corporations is that the particular corporation shall at the end of each financial year report to the appropriate minister on the exercise and performance of its functions and on its policy and programs, and the minister is under obligation to lay a copy of every such report before each House of Parliament. The report is to set out any direction given by the minister to the corporation unless he has notified the corporation his opinion that it is against the national interest or in some cases (e.g., electricity, transport, gas, iron and steel) against the interests of national security to do so. ${ }^{16}$ In the case of the Iron and Steel Corporation, a direction can also be omitted from the report if the minister accepts the contention of the corporation that it is contrary to the commercial interests of the corporation to publish it.

Particular attention has been paid by the major corporations to the need for publishing substantial reports in fulfillment of the statutory requirement, the more so as the reports are presented to Parliament and opportunity is afforded by the Government for general debates on their contents. The National Coal Board set the example of what a report should contain in its second report of 1948 and that example was followed by the British Transport Commission and the British Electricity Authority. These reports contain from 300 to 400 pages in octavo book form, about one-half consisting of well compiled chapters setting out the progress made in connection with the various activities of the corporation, together with its organization and plans for development, and the second half containing the yearly accounts and appendices giving general statistics in relation to the work of the corporation. These reports are reviewed in the press and members of both Houses of Parliament study them in readiness for the debates thereon. The inauguration of a number of public corporations by Parliament dominated by a socialist government has taken place during a difficult period of post-war economic fluctuations, and criticism of their working has been freely expressed by members of both Houses of Parliament mainly because many of the corporations have not been able to show trading profits or to avoid increased charges for their products or services. There has been an insistent

${ }^{10}$ Coal Industry Nationalisation Act, I946, §54; Transport Act, $1947, \S 4$; Electricity Act, x947, §8; Gas Act, I948, §10; Iron and Stecl Act, I949, $\$ 4$. 
demand for the setting aside in Parliament, particularly in the House of Commons, of adequate time for debate of each of the yearly reports of the respective corporations.

When the first annual report of the National Coal Board for the year 1948 was considered in the House of Commons, ${ }^{17}$ the then Minister of Fuel and Power (Mr. Gaitskell) commented on the relationships between Parliament, the Minister, and the Board, stressing the fact that the powers of the Minister were limited in relation to the affairs of the Board, the Minister being accountable to Parliament for the way in which he discharged the powers conferred on him and for anything done by civil servants acting in his name and subject to his authority. He pointed out that the creating Act conferred two kinds of powers on the Minister, viz., (a) specific powers as regards capital investment, research, training, education, and health and safety of the workers and, on the financial side, direction of capital charges and interest, form of accounts, and appointment of auditors; and (b) general powers, first as to direction in matters affecting the national interest and secondly as to the appointment of members of the Board. The Minister would thus be responsible for the use made of his specific powers and, in relation to the general powers, he would be answerable for the general success or failure of the enterprise but not for the day-to-day management and administration of the industry by the Board or the operations of the Board in the provision and selling of coal or the management of ancillary activities. He concluded that, if, after consideration of the annual reports of the Board, Parliament considered that the Board had seriously failed to carry out the duties and functions imposed upon it, Parliament could call the Minister to account for failure to appoint suitable members to the Board or to issue suitable general directions to the Board. In the last resort, Parliament could, by legislation, alter the powers and functions of the Board.

This represents the constitutional position as regards the relationships discussed. Otherwise, debate on an annual report of a public corporation provides an occasion for the review by Parliament of the affairs of the corporation in some such manner as once a year the shareholders of a company discuss the report issued by the company directors. Where constructive criticisms are made in the course of the debate, the minister concerned can take cognizance of them and at a suitable time bring them to the notice of the responsible corporation. But, if he does not accept the criticisms, he can by use of the government political majority avoid giving effect to them. Parliamentary control is thus not absolute. Strong pressure can be brought to bear upon the minister during the debate in the hope that he will promise to take some action on the point raised but there is at the present moment no method by which Parliament can enforce or supervise the application of measures necessary to introduce any reforms which may be advocated. The practical value of discussions on annual reports thus resides mainly in the fact that the debates are studied by the government departments who advise ministers as to future action and by the staffs

${ }^{17}{ }_{469}$ H. C. DEB. 1419 et seq. (5th ser. 1949 ). 
of the various corporations who are thus able to assess how far their policies are likely to be accepted by the public and what reforms should be undertaken in order to secure a relaxation of future criticism.

The position taken by the responsible ministers in relation to the debates on these annual reports of corporation has been that of defenders of the policy carried out by the corporations concerned, and ministers have been at pains to counter expected criticisms in advance. Thus in the debate on the 1949 report of the National Coal Board, ${ }^{18}$ the Minister of Fuel and Power stressed the effort made to increase production, the total of 202 million tons obtained showing an increase of 28 million tons over the figure for 1945 and 5 million tons over that for 1948 . As regards the trading loss incurred, the Minister pointed out a progressive improvement in as much as in 1947 there was a loss of $\delta_{23} 1 / 2$ million, in 1948 a surplus of $£^{1} 1 / 2$ million, and in 1949 a surplus of $£ 91 / 2$ million. He stated that the Board hoped to liquidate the outstanding loss in $195^{\circ}$ and to start building up a reserve. In the debate $^{19}$ on the first reports of the British Electricity Authority and the Area Electricity Boards covering the period 1947 to I949, the Minister of Fuel and Power drew attention to two special difficulties which had been met, viz., (I) delays in securing deliveries of new generating plant, and (2) the curtailment of supply by loadspreading and load-shedding. As regards financial results, he pointed out that the British Electricity Authority incurred a loss of $\$ 600,000$ on current supplied to area boards whereas the boards made a surplus of some $£ 5$ million on dealing with industrial and domestic consumers, the net surplus thus being $f, 4,400,000$ on a total revenue of nearly $f_{\mathrm{I}} \mathrm{g} 8 \mathrm{million}$.

As regards transport, in the course of the debates in the House of Commons on the annual reports for 1948 and $1949,{ }^{20}$ the Minister of Transport (Mr. Barnes) referred to the world-wide problem of railway finance, few systems (including even those in the United States and Canada) making a profit. He confirmed the government policy of making up the loss by the process of integration (i.e., exercising the utmost economy while securing efficiency and cutting out all waste) rather than by the grant of subsidies which would transfer from the industry to the taxpayer the burden of making up the loss. He did not consider it feasible to repudiate the interest charge on British Transport Commission stock which worked out at about 3 per cent and could not be considered as heavy. He stated that it had been necessary to extend by a further period of two years the statutory time-limit of two years from the passing of the Transport Act, I947, for the production of general charges schemes. He pointed out that the railways had suffered from road competition, partly from A and B license holders (entitled to carry other persons' goods either generally or together with their own goods) who had a fleet of some 129,000 vehicles as against the Road Haulage Executive's fleet of 35,000 vehicles, and partly from $\mathrm{C}$

${ }^{18} 477$ id. 1557 et seq. (5th ser. 1950 ).

${ }^{29} 478$ id. 247 et seq.

${ }^{20}$ Id. at 2056; 479 id. 1347 et seg. 
license holders (entitled to carry their own goods in their own vehicles) who had increased their fleet from some 590,000 vehicles in 1948 to some 699,000 vehicles in June 1949 .

\section{Questions Asked by Members in Parliament}

The method of eliciting information from ministers by questions asked by members of the House of Commons or the House of Lords is one that has developed to such an extent that it has become a significant part of parliamentary procedure. The greatest development has taken place in the House of Commons where a time for answering questions is allotted regularly at the commencement of proceedings. In the House of Lords questions are occasionally (but not frequently) put and answered in much the same way as in the House of Commons, the answers being given by a member of the House designated by the government for that purpose since the questions cannot be put direct to ministers who usually sit in the lower House, the House of Commons. The main interest, therefore, from the point of view of parliamentary control arises from the procedure of the lower House.

It is the practice of the House of Commons to allow members to ask questions of ministers relating to

(a) the public affairs with which they are officially connected;

(b) proceedings pending in Parliament; or

(c) matters of administration for which they are responsible. ${ }^{21}$

The ministers either reply orally in the House or, if the answers are lengthy, circulate written replies with the printed debates. This practice subjects ministers to constant challenge on matters of administration and in order to relieve them from this burden in relation to the activities of public corporations the principle has become established that they should not be subject to questions on the day-to-day management of the corporations. Sir John Anderson in a Romanes lecture delivered in May, 1946, on the subject of public corporations stated the principle as follows: "In regard to matters falling within the Minister's power of control, he would be liable to be questioned in Parliament in the usual way. On the other hand, in regard to matters declared to be within the discretion of the authority, the Minister would be entitled, and indeed bound, to disclaim responsbility." The principle is designed to avoid the criticism levied against state departments that they are afraid to take risks and are slow in movement largely for the reason that they are accountable to the House of Commons for their actions. Public corporations being highly commercial, industrial, and economic bodies, are better run if free from meticulous accountability to political channels, which would curb their commercial enterprise and hamper the recruitment of the best men to their service, since such men are likely to resent submission to a process of constant pin-pricking by way of parliamentary questions.22 In carrying this principle into effect, ministers have incurred considerable unpopu-

\footnotetext{
${ }^{21}$ See T. Erskine May, Parliamentary Practice 334-338 (London, I4th ed. 1946).
}

22448 H. C. Deb. $454-456$ (5th Ser. 1948). 
larity and members have constantly expressed their disappointment and dissatisfaction when ministers have refused to answer their questions or the clerks at the table have declined ta put them on the order paper on the ground that they repeated in substance questions already answered or to which answers had already been refused. As a result of considerable pressure on the part of members, the rule against the repetition of questions to which answers have already been refused has been relaxed and those questions are allowed provided that, in the opinion of the Speaker which is not open to discussion in the House, the matters raised are of sufficient public importance to justify their appearance on the order paper. ${ }^{23}$ The minister can still use his discretion as to whether he will answer the question as he may very well be guided by considerations of which the Speaker has no knowledge.

The general principle which has been established is that questions can be put to ministers in relation to public corporations

(a) where the minister has done something; and

(b) where the minister has power to do something and has not used the power.

In effect the specific powers of the ministers vary with the different corporations but in each case they cover a wide range including the appointment, salaries, and conditions of service of board members; programs of research and development and of education and training; borrowing by the boards; the form of accounts and audits; annual reports; pension schemes and compensation for displacement; the appointment of consumers' councils; and various matters connected with organization and operation.

Members who question ministers usually do so either to obtain factual information of a general or statistical kind which can be produced from the departmental records or to ventilate grievances in order to ascertain the remedies available. Questions which come within the former category are not usually resisted by the minister but it occasionally happens that the information is kept by the particular public corporation and not by the ministry. In such cases, the minister may obtain the information and pass it on to the questioner or he may state that the required particulars are not available in his department. For instance, the Minister of Transport in answering a question on one occasion ${ }^{24}$ about the salary of the chairman of the Port of London Authority stated that he gave the information by courtesy of the Port of London Authority. Questions within the second category relating to grievances receive varying treatment from ministers. Sometimes the minister will explain the policy out of which the alleged grievance arises. At other times he will avoid answering the question on the ground that the matter is one for settlement by the public corporation concerned. In such a case the person aggrieved cannot rely on any parliamentary control over the corporation and is left to his own

\footnotetext{
${ }^{23}$ Statement by Speaker in House of Commons Debates, $45 I$ H. C. DEB. 1635-1643 (5th ser.
} 1948).

${ }^{24} 42$ I H. C. DEB. $807-808$ (5th ser. 1946). 
resources to make his grievance known. He can approach the corporation direct or through the member of Parliament representing his locality. If he fails to obtain satisfaction, he can submit his grievance to the appropriate consumers' council, which can, if it so decides, pass on the complaint to the minister who has powers to direct the public corporation to remedy the defect disclosed by the representations. ${ }^{25}$

The following examples of answers given to questions illustrate the principles explained above. The references are to House of Commons debates containing answers.

How many cases of personal injury by explosives in domestic coal have been reported to the Minister's department, in how many cases was compensation paid and by whom? Answer: Thirty-three cases, though there is no statutory obligation of report to the Minister. The Minister said he had no information on the second and third parts of the question. ${ }^{26}$

How many tons of opencast coal were sold during the year ending March 31, 1948, and at what price? Answer: The tonnage was 10,511,000 and the average price was 395.7 d. a ton. ${ }^{27}$

Whether steps are being taken to make dust suppression compulsory at all pits? Answer: Measures are being developed under a voluntary scheme agreed upon by the Minister of Fuel and Power with the National Coal Board and the National Union of Mineworkers. ${ }^{28}$

Question asked for a statement on the closing of pits in the Yorkshire area. Anstver: Four pits have been closed. Over the next ten years the winding of coal from about twenty pits may cease. Final plans will be settled by the National Coal Board as part of its long-term reorganization plans for the country. ${ }^{29}$

On what principles are men to be selected by the National Coal Board for dismissal as redundant? Answer: This is a matter for the Board to decide. ${ }^{30}$

Whether arrangements would be made to publish the amounts paid and the names of those to whom payment had been made by nationalized undertakings for loss of office and emoluments? Answer by the then Lord President of the Council (Mr. Herbert Morrison): The settlement of individual cases of compensation for loss of office is a matter of the day-to-day administration of the boards of the socialized industries. ${ }^{31}$

The Minister of Fuel and Power answered one question relating to the effect of the cut in the capital investment program and its effect in curtailing electricity supplies in rural areas, and three questions dealing with the steps taken by the Minister's department to increase manpower in coal pits, the terms upon which the National Coal Board markets coal from opencast mining as agents of the Minister, and the additional annual tonnage of coal per man year due to the introduction of machinery. ${ }^{32}$

Question asking for a statement on the posters displayed by the British Electricity Authority headed "Another New Power Station" (The imputation was that the posters were misleading as none of the new power stations advertised had so far been built). Answer: This deals with a matter affecting the day-to-day administration of the Authority on which it would not be desirable for the Minister of Fuel and Power to comment. The

${ }^{25}$ See, for example, Coal Industry Nationalisation Act, r946, $\$ 4$.

${ }_{28}^{28} 453$ H. C. DEB. 30 (5th ser. 1948) (written answer).

$2 \pi 453$ id. 577 .

20454 id. 556.

${ }^{31} 47^{6}$ id. 1290 (5th ser. 1950).

${ }^{28} 453$ id. 123 (written answer).

so 456 id. 33 (written answer).

32477 id. $1829-33$. 
Minister said that on matters of general policy he was always ready to answer questions. ${ }^{33}$

Request to Minister of Fuel and Power for a statement on the general policy of advertising by the British Electricity Authority. The Minister said that while advertising was a matter of commercial management for which he had no direct responsibility, since the question appeared to raise a matter affecting the public interest, he had, without creating a precedent inconsistent with the present practice, asked the Authority to inform him about. its policy in the matter. The policy was that it wished (a) to assure customers that it was bringing plants into commission as quickly as it could, and (b) to induce householders and office workers to help industry by limiting their use of electricity during the hours of peak demand. ${ }^{34}$

\section{Parliamentary Debates on General or Particular Matters}

\section{Affecting Public Corporations}

Various opportunities for debating matters affecting public corporations arise in the course of the parliamentary program which is usually fixed by the government after consultation with the leaders of the opposition. The setting up of a series of public corporations to deal with industries newly nationalized has attracted a considerable amount of parliamentary attention. In the earlier stages, from 1946 onwards, the socialist government with a large majority could impose its will upon Parliament with greater ease than has been possible since its re-election in February I950 with a very small majority. It is not surprising, therefore, to find that, whereas formerly the amount of time allocated for debates on the public corporations was somewhat limited, the present practice-shows signs of relaxation and there is a more generous allocation of parliamentary time for the purpose of considering the many issues raised by members many of whom are extremely critical of the methods used by the corporations and dissatisfied with their practical results. Debates thus take place in the House of Commons and in the House of Lords during the parliamentary session and divide themselves into two main classes (a) full general debates extending over the greater part of a day or in a few cases over several days; and (b) short debates on particular matters.

As regards full general debates, these may be the basis for discussion of principles affecting public corporations generally or of the activities of a particular corporation. Such debates may take place on the consideration of the King's speech at the opening of a parliamentary session, on supply days when departmental estimates are under consideration and the minister concerned has responsibilities for a particular corporation, or on days allocated by the government either for the purpose of discussing the annual reports of the various corporations or in view of a general desire by members to discuss matters affecting one or more corporations. Debates in connection with the King's speech took place in November, $1948,{ }^{35}$ when consideration was given to an amendment regretting the persistence by the government in a policy of nationalization which had imposed heavy burdens on consumers and taxpayers

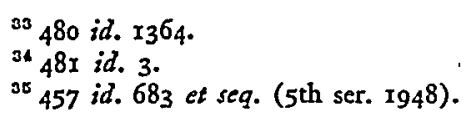


and was impeding the enterprise essential to recovery. In the debate on the King's speech in November, I950, there was no prolonged discussion of the nationalized industries but they were referred to in both Houses of Parliament, viz., in the House of Commons when regret was expressed that there was no reference in the Speech to methods whereby Parliament could keep control over nationalized industries and suggestions were made for reducing the losses on transport, ${ }^{36}$ and also in the House of Lords when the government was criticized for failing, as regards nationalized industries, to hold the balance between the advantages on the one hand of assured financial resources and a monopoly and the disadvantages on the other hand of inflexibility and loss of competition. ${ }^{37}$

On supply days when the estimates of particular departments are examined, the opposition have an opportunity of choosing subjects needing debate and can where they so desire select the activities of a particular corporation. Thus in March i $950^{38}$ when votes on account were under consideration, the House of Commons discussed the transport industry generally. Later when the estimates of the Ministry of Transport were considered, the House debated the subject of road haulage ${ }^{30}$ and when the estimates of the Ministry of Fuel and Power were in issue the subject chosen was the working of opencast coal. ${ }^{40}$ A further discussion took place on the subject of civil aviation and the powers of the British Air Corporations. ${ }^{41}$ Debates also took place in the House of Lords on the policy of the British Transport Commission $^{42}$ and on redundant staff arising out of the merger of the staffs of the British Air Corporations. ${ }^{43}$

As regards the allocation of special days for discussions, the Lord President of the Council undertook in March $1950^{44}$ to allocate three ordinary days before the end of July for debates on socialized industries and in due course debates took place on the annual reports of the National Coal Board, the British Electricity Authority and the Electricity Area Boards, and the British Transport Commission. ${ }^{45}$ General debates on the efficiency and accountability of the socialized industries also occurred in the House of Lords ${ }^{46}$ and the House of Commons, ${ }^{47}$ and a special debate was held on an opposition motion in the House of Commons as to the nationalization of the iron and steel industry. ${ }^{48}$

As regards short debates on particular matters, these arise at frequent intervals on motions for the adjournment of the House of Commons, on prayers in either House of Parliament for the annulment of subordinate legislation (such as regulations) made by the ministers concerned and laid on the table of the two Houses, and on

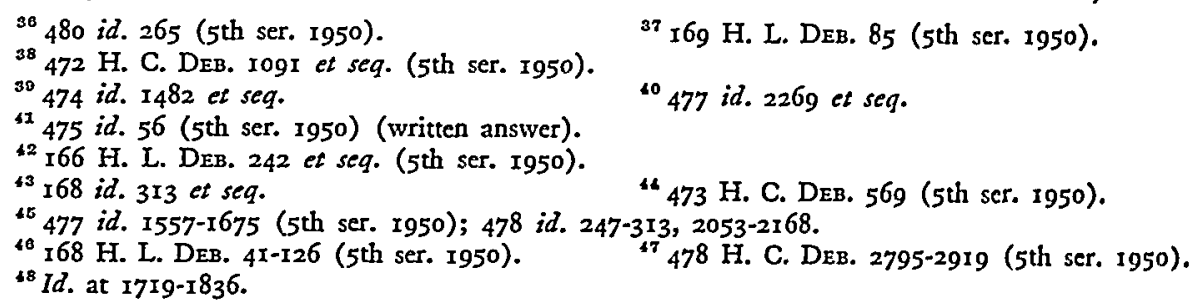


private bills introduced in Parliament by the nationalized industries in order to secure local improvements or to acquire private property. Members of both Houses have been astute to seek occasions for debating a variety of subjects affecting public corporations by means of these short debates. In the House of Commons, members have sometimes used their opportunities to raise on the adjournment of the House matters arising out of questions refused at the table of the House or unanswered by the ministers concerned. Attention has been drawn in this way to the vexed question of dwelling-houses tied to railways and the difficulties arising when railway employees on retirement have been asked to give up their houses for use by other railway employees. ${ }^{49}$ Other matters raised in this way include rural bus services on uneconomic routes, ${ }^{50}$ road passenger transport in Scotland, ${ }^{51}$ and road haulage..$^{52}$ Prayers for the annulment of regulations have also frequently provided opportunities for debate. Thus the motion by the Minister of Transport for approval of the Draft Transferred Undertakings (Compensation to Employees) Regulations $195^{\circ}$ led to an argument how far road haulage was a monopoly of the British Transport Commission. ${ }^{53}$ Similarly a prayer to annul the Electricity (Severance Compensation) Regulations $195^{\circ}$ made by the Minister of Fuel and Power provided an opportunity for ventilating the grievance of local authorities arising out of the delay in distribution of moneys from the compensation fund without any payment of interest in respect of the delay. ${ }^{54}$ Further opportunities for short debates are afforded when a public corporation introduces a private bill to carry out local works in the nature of improvements of its system of working or to acquire land in particular localities for that purpose. These bills must pass their second reading stage on the floor of the House in the Commons and members can block the second reading until an opportunity is granted in the parliamentary program for debate. Thus when the British Transport Commission's private bills of 1949 and 1950 were before the House of Commons the Speaker of the House in the first case and the Deputy-Speaker in the second case ruled that the debate might extend beyond the contents of the bill but should remain related to its purpose and not traverse the constitution and powers of the Commission which had already been settled by Parliament. ${ }^{55}$ In the case of the 1949 bill, the general questions discussed included the high cost of passenger fares on the railways as compared with the fares charged by the coach services, the need for adjustments in workmen's and school children's fares on the railways, the overcrowding of London transport, and the need for reducing redundant railway staff. In the case of the I95o bill, the debate ranged over the financial problem of the railways and raised the question whether the deficit was to be met by an increase in charges. The Minister of Transport (Mr. Barnes) gave

\footnotetext{
${ }^{10}$ Id. at $828-838$.

E1 478 id. $2188-2196$.
476 id. 2338-2356; I67 H. L. DEB. 1236-124x (5th ser. r950).

478 H. C. Deв. 2173-2r 88 (5th ser. r950).

${ }^{\text {Ex }} 46 \mathrm{I}$ id. 177I et seq. (5th ser. 1949); 473 id. 655 et seq. (5th ser. 1950).

${ }^{50} 474$ id. 564-572.

474 id. I262-I272, I $482-1540$.

(5th ser. r950).
} 
a full account of the progress of the discussions which had taken place in order to arrive at a solution of the problem and explained the increase in costs (such as higher prices of steel and timber) which had to be met. He argued that Parliament must make up its mind whether the situation was to be adjusted by an increase in the form of a subsidy which would fall on the taxpayer or by the normal process followed by industrial undertakings of adjusting charges to the cost of the services they themselves received. The only check on the debate enforced by the DeputySpeaker was discussion of the question of London passenger transport fares which was being considered by the Transport Tribunal at that moment and was therefore ruled out of order as being sub judice.

\section{E. Reports of Parliamentary Investigating Committees}

Two committees of the House of Commons are charged with the duty of investigating the expenditure of public monies, viz., the Public Accounts Committee and the Estimates Committee. The Public Accounts Committee is a sessional committee appointed by the House under standing order 74

(a) to examine the appropriation accounts and re-check the appropriation audit in order to ensure that no sums have been expended on purposes other than, or in excess of, those for which they were granted by the House;

(b) to report on any excess vote presented; and

(c) to recommend improvements in the form and method of the national accounts.

The committee maintains close relations with the Treasury and the Comptroller and Auditor General whose reports serve as a basis for their inquiries. ${ }^{50}$ The Estimates Committee is a sessional committee of the House, its duties being to suggest the form in which the estimates should be presented for examination and to report what, if any, economies consistent with the policy implied in those estimates may be effected therein. The work of the committee does not begin until the estimates have been presented to the House when their form is practically final. Proposals to secure earlier submission of the estimates to the committee and to bring the policy of the estimates within its purview have been resisted as clashing with the doctrine of ministerial responsibility. ${ }^{\mathbf{5 7}}$

These two committees are already overloaded with a considerable volume of work and it has been suggested that a new committee should be set up advised by a new official similar to the Comptroller and Auditor General with a general responsibility for investigating the accounts of the nationalized corporations. This suggestion has been resisted by the government on the grounds explained by the Lord President of the Council ${ }^{58}$ that it would detach the members of the boards of the public

\footnotetext{
${ }^{50}$ Gizbert Campion, Introduction to the Procedure of the House of Commons 279 (London, 2d ed. 1947); T. ERskine May, Parliamentary Practice 644 (London, I4th ed. 1946).

${ }^{87}$ Campion, op. cit. supra note 56, at 280.
} 
corporations from their duties and subject them to harassing cross-examination by a parliamentary committee and would tend to diminish rather than encourage their initiative in the enterprise for which they are responsible. If, however, members of Parliament are to carry out their duties as guardians of public expenditure, there seems no valid reason why they should not be granted an opportunity through the instrumentality of a committee of this nature to investigate the accounts of the public corporations and when occasion arises to criticize expenditure that has been unwisely incurred. It is true that criticism of this nature made long after the event cannot redeem any consequential financial loss but it can issue a timely warning against the continuation of a policy which would be likely to lead to similar losses in the future.

Although the government has not been in favor of regular reviews of the work of public corporations through the medium of the accounts committee, it has conceded $^{\text {ED }}$ the desirability of establishing periodical reviews, say every five or seven years as has been done in the case of the British Broadcasting Corporation. These reviews would be conducted by a body of persons nominated by the minister concerned and that body would include a limited number of members of Parliament. In this way the reviewing body would be associated with Parliament indirectly without the stricter control of the select parliamentary committee. The reviewing body would make a report which would be available to Parliament and the public, and the government could be questioned in due course by members of Parliament as to how far any recommenadtions for improvement made in the report had been carried out. This suggestion should certainly be put into force as it would enable the reviewing committee to recommend general alterations in the policy and structure of the corporations after mature consideration, thus avoiding meticulous interference with their day-to-day commercial efficiency.

\section{II}

\section{Ministerial Control}

\section{A. Directions by the Minister}

Definite statutory powers of direction have been conferred on the ministers responsible for the public corporations. The model provision is that contained in Section 3 of the Coal Industry Nationalisation Act, 1946, which enables the Minister of Fuel and Power, after consultation with the National Coal Board, to give the Board directions of a general character as to the exercise and performance by the Board of its functions in relation to matters appearing to the Minister to affect the national interest. Similar powers are conferred on the Minister of Fuel and Power in relation to the British Electricity Authority, the Area Gas Boards, and the Gas Council; on the Minister of Transport in relation to the British Transport Commission; on the Minister of Civil Aviation in relation to the British Overseas

\footnotetext{
${ }^{50}$ Id. at 2912.
} 
and the British European Airways Corporations; and on the Minister of Supply in relation to the Iron and Steel Corporation. ${ }^{60}$ Further provisions usually require the public corporation concerned to act on lines settled from time to time with the approval of the minister in framing programs of reorganization or development involving substantial outlay on capital account or in the exercise of its functions in relation to training and education of personnel as well as to research. The corporation is also under obligation to afford to the minister facilities for obtaining information with respect to its property and activities and to furnish him with returns and accounts and other information for that purpose. Where the corporation is substantially subsidized by the government, as in the case of the British Air Corporations, the program of activities and the estimated revenue therefrom has to be submitted annually to the minister in order that the amount of annual subsidy may be duly assessed in respect of such activities as the minister sanctions. ${ }^{\text {g1 }}$

These are important powers of direction and the corporation concerned is usually under obligation to include in the annual report of its activities any directions given by the minister in the course of the year unless the minister has notified to the corporation his opinion that it is against the national interest to do so. ${ }^{02}$ In fact, these powers of direction have been sparingly used by ministers and the criticism has been advanced that greater use of these powers should be made. Mr. Ernest Davies writing in the Political Quarterly in $195^{63}$ as a member of Parliament stated that ministers, in preference to making use of their statutory powers of direction, took advantage of the existence of the powers to influence the public corporations by consultation, thereby exercising their powers behind closed doors since no information was available to the public as to how far the corporation had acted with or without the advice of the minister. Mr. Herbert Morrison in his capacity as Lord President of the Council has defended this attitude ${ }^{64}$ on the ground that the success of the system of dual control of nationalized industries by ministers and corporate boards depends on the maximum harmony between the ministers and the boards. $\mathrm{He}$ deprecates the indiscriminate use of directions by the ministers to ride roughshod over the boards. He prefers the government practice of relying upon persuasion by the minister to influence the boards.

Members of Parliament have from time to time recounted difficulties met in the operations of public corporations and have asked the minister concerned what directions of a general character he would give to obviate the difficulties. Thus one typical complaint made by way of question ${ }^{65}$ related to delays in the payment of

${ }^{60}$ Electricity Act, 1947, §5; Gas Act, 1948, \$7; Transport Act, 1947, \$4; Air Corporations Act, 1949, 12, I3 \& I4 GEo. 6, c. 91, \$5; Iron and Steel Act, 1949, \$4.

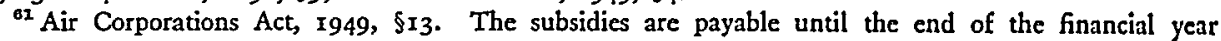
r955-1956.

${ }^{62}$ See, for instance, the Coal Industry Nationalisation Act, $1946, \$ 54$. (1950).

${ }^{\mathrm{B}}$ Ministerial Control and Parliamentary Responsibility of Nationalised Industries, 21 PoL. Q. 150

${ }_{04}$ Public Control of the Socialised Indtustries, 28 PuB. ADM. 3 (1950).

${ }^{65}{ }_{467}$ H. C. DEB. I795 et seq. (5th Ser. 1949). 
compensation to road haulage firms whose businesses had been acquired compulsorily by the British Transport Commission. The reply of the Minister of Transport was that he did not consider it necessary to give any direction to the Commission on the matter but, on being pressed by other members of the House to state his reasons, he explained that the delays arose from the need for identifying the property concerned and verifying the legal titles thereto and said the details of any particular case could be submitted to the Commission but under further pressure finally admitted that they could be submitted to him as well. Another question put to the Minister of Fuel and Power ${ }^{6 b}$ asked what directions he proposed to give to the British Electricity Authority to encourage area boards to install diesel plants for the supply of electricity to isolated farms in sparsely inhabited localities. The Minister stated that he could not issue general directions of the kind proposed since it was the duty of the Authority and the area boards to decide what is the best method of supplying electric current to any particular consumer. He added that, if the questioner had any suggestions to make about a special district, he was sure the area board concerned would be glad to consider them. Ministers have thus consistently avoided the giving of directions to public corporations even in cases where the decision to take a particular course of action has manifestly emanated from the minister. This was the case in the application of the proposals of the Clow Committee for a seasonal variation in domestic electricity charges whereby consumers paid a surcharge in the winter for their supply and received a rebate in the following summer, the underlying intention being to induce consumers to use less electricity in winter when the load was greatest and the price high. The Minister of Fuel and Power stated, in reply to a question on the point, ${ }^{67}$ that he had not given any directions to the electricity area boards but had asked them to put the recommendations of the Clow Committee into effect. On another occasion when, in the course of an adjournment debate, ${ }^{68}$ joint meter reading by the electricity and gas boards in a particular area was advocated in order to save manpower, the Minister of Fuel and Power stated that it would not be proper for him to use his powers of direction on a small matter of this kind and that he could only intervene if strong representations were made to him by one of the consultative councils or if he thought that it was a matter of general policy that affected the national interest. He explained that the electricity and gas councils for the area concerned had decided to carry out separate meter readings as they wished their respective agents not only to read meters but to advise consumers about services and appliances available and take instructions for repairs to plant and apparatus. Again when a member, during an adjournment debate, ${ }^{68}$ called attention to hardships suffered by railway employees pressed by the Railway Executive of the British Transport Commission on their

${ }^{00} 480$ id. 1366 (5th ser. 1950).

${ }^{\circ 7} 457$ id. 128 (5th ser. 1948) (written answer).

${ }^{68} 476$ id. 824 et seq. (5th ser. x950).

${ }^{60} 478$ id. 83 I-840. 
retirement from service to give up their tied houses for use by other railway employees and argued that a public corporation should not use legal powers of eviction in such cases, the Minister of Transport stated that he could not direct the Railway Executive not to take advantage of the law as provided by Parliament for that purpose. He added that the Executive, faced with the difficulty of shortage of accommodation for its employees, had tried to act reasonably but it sometimes had to resort to powers of reference to the courts for a decision in a particular case.

An examination of the various annual reports issued by the public corporations shows that directions given to the corporations by the ministers have been confined to financial directions on such matters as repayment of capital advances and interest on loans and payment of interim interest to stockholders. ${ }^{70}$ The working out of the relations between the ministers and the corporations for which they are responsible would have been clearer to members of Parliament and to the public if the ministers had made greater use of their powers of giving general directions. Important lines of policy would thus have become evident and their incorporation in the annual reports of the corporations would have provided an opportunity for further examination in the light of the results attained.

\section{B. Consultation on Policy}

As indicated above, ministers have preferred to rely on consultation and persuasion in relation to public corporations rather than on powers of direction, and Mr. Herbert Morrison in his capacity as Lord President of the Council has supported that preference ${ }^{71}$ on the ground that for reasons of national social and economic policy the corporations must do things which they would not do if they were influenced solely by commercial motives. Thus the government may wish a corporation to embark on a project, not necessarily unprofitable, but unpopular or speculative. If the corporation disagrees with the project, in the absence of a formal direction from the minister, it is difficult to see what protection the corporation would have other than a public announcement that the action taken is at the request of the minister. As Mr. Morrison points out, such an announcement would be looked upon as evidence of disharmony between the corporation and the minister and would open the way to political controversy. On the other hand, if the corporation is pressed by the minister to undertake a measure which is likely to result in financial loss, the ultimate reaction may very well be a request by the corporation to the minister to subsidize the loss, which it is the government's general policy to avoid since the corporations are mainly intended to balance expenditure against income over a period of years. A question on this matter was directed to the Minister of Fuel and Power in June I9 $48^{72}$ when he was asked what steps he had taken to maintain contact with the

\footnotetext{
${ }^{70}$ See Annual Report of National. Coal Bonrd for 1948 App. VI, and First Annual. Report of British ELEcTricity Authority For I947-1948 App. 40.

${ }^{71}$ Public Control of the Socialised Industries, stupra note 64 , at 4 .

72452 H. C. DeB. 643 (5th ser. I948).
} 
operations of the National Coal Board and the British Electricity Authority, whether regular consultations were held, and whether individual members of these corporations were free to consult him on matters of policy. The minister replied that he had made a practice of informal contact personally with the chairmen of these corporations at frequent intervals and that consultations with the corporations were held when occasion demanded, but that individual members of the corporations would not be free to consult him on matters of policy, such matters being the responsibility of the corporation as a whole.

It is evident that consultations between ministers and corporations must form an important element in securing the adoption and pursuance of policies designed to enable the corporations to carry out their functions to the best possible advantage of the consumers or users of their products or services, due regard being paid to the avoidance of financial loss. Those consultations must be confidential and it is not a legitimate subject of complaint that they are held behind closed doors. It must be left to the parties concerned, the minister on the one hand and the corporation on the other, to recognize their joint responsibility for the ultimate success of a particular enterprise. If failure ensues, with consequential insolvency, then, in the words of Mr. Morrison, the minister will have to take the lion's share of the blame.

\section{Financial Control}

The main financial liabilities of a public corporation in respect of capital arise from its obligations to pay compensation for assets acquired by it from other persons and bodies on its creation, and thereafter from the cost of providing capital equipment and working capital for the implementation of replacement or improvement schemes. The corporation is generally authorized to raise the necessary capital by the issuance of stock and the control of the minister concerned acting in concert with the Treasury is applied at various stages in the issuance of the stock. As regards revenue and outgoings, the public corporation is generally expected to achieve a balance taking one year with another. The establishment of adequate ministerial control over the finances of the corporation is obviously an important matter and is usually secured in the following manner by the statute creating the corporation or by regulations made by the minister thereunder.

Taking the electricity industry as a typical case, the Central Authority (the British Electricity Authority) is under an obligation to issue stock, known as "British Electricity Stock," for the purpose of satisfying compensation rights and has a discretion as regards the issue of stock needed for capital works or working capital or the redemption of stock. ${ }^{73}$ The amount of stock which may be issued otherwise than for compensation purposes is limited to $£ 700$ million and is subject to the consent of the Minister of Fuel and Power and the approval of the Treasury. ${ }^{74}$ Stock issued for compensation purposes is guaranteed by the Treasury and, if issued for

73 Electricity Act, $1947, \$ 40$.

7" 1 d. $\$ 39$. 
other purposes, may be so guaranteed. ${ }^{75}$ The manipulation of the stock, including the date, method, and price of issue, the rate of interest, and the conditions for redemption are subject to similar ministerial consent and Treasury approval under the regulations ${ }^{76}$ made by the Minister. Since the Central Authority is the main financial agency for the industry, it alone exercises these main borrowing powers to the exclusion of the Area Electricity Boards. The Central Authority and the Area Boards may, however, borrow moneys temporarily for the purposes of their functions subject to the consent of the Minister and the approval of the Treasury or in accordance with any general authority issued by the Minister with Treasury approval. ${ }^{77}$ Compensation stock, mostly consisting of British Electricity 3 per cent guaranteed stock I968-1973, has been issued to a total of (approx.) $£ 342$ million, and stock for new money has been issued in the form of froo million British Electricity 3 per cent stock $1974-1977^{78}$ If the Treasury is called upon to provide moneys under any of its guarantees, those moneys are repayable by the Central Authority to the Treasury at such rate as the Treasury may fix and in such manner and over such period as the Treasury may determine after consultation with the Minister. A statement as to any guarantee given and as to any sum issued out of the consolidated fund to meet it is to be laid before each House of Parliament. ${ }^{79}$

The Central Authority is under obligation to maintain a general reserve fund, to which the Central Authority and the Area Boards contribute such sums as the Central Authority may determine, and the Minister has power to give directions to the Central Authority as to the establishment, management, or application of the fund or the carrying of sums to the credit of the fund. Area Boards may also establish general reserve funds and may contribute to the funds such sums as the Central Authority may approve. The Central Authority with the approval of the Minister may give the Area Boards directions as to the establishment or management of the reserve funds and the crediting of sums thereto. The main purpose of these reserve funds is to prevent frequent fluctuations in the charges made by the Central Authority and the Area Boards. ${ }^{80}$ Surplus revenues of the Central Authority for any financial year may be applied as the Authority may determine subject to any directions which the Minister may give with the approval of the Treasury. Surplus revenues of any Area Board are to be applied for such purposes as the Board with the approval of the Central Authority may determine. ${ }^{81}$ The sums chargeable by the Central Authority and the Area Boards to revenue account include the usual trading charges, allocations to the central reserve fund, and provision for redemption of capital and for depreciation or renewal of assets. ${ }^{82}$ It is the duty of the Central

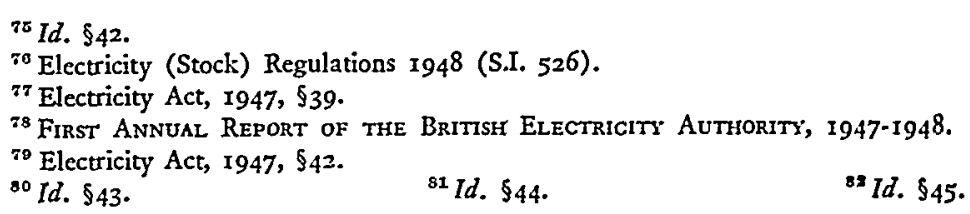


Authority and the Area Boards to keep proper accounts and to prepare in respect of each financial year a statement of accounts conforming with the best commercial standards in such form as the Minister may direct with the approval of the Treasury. The form of accounts was laid down by the Minister in the Area Boards (Accounts) Direction $1949^{83}$ and included directions as to showing separate items of income and expenditure on revenue account, analyses of income and expenditure, classification of assets and liabilities for the balance sheet, categories of assets and provision for depreciation, book and market values of investments, and outstanding loans to personnel. The accounts of the Central Authority and the Area Boards are audited by auditors appointed in respect of each financial year by the Minister. Statements of the accounts with copies of the auditors' reports are sent by each Area Board to the Central Authority and by the Central Authority to the Minister whose duty it is to lay copies of the statements and the reports before each House of Parliament. ${ }^{34}$

Powers of a similar nature provide for control by the Minister of Transport in relation to the functions of the British Transport Commission, ${ }^{85}$ which is assisted by public corporate bodies known as executives who act as agents for the Commission and exercise such functions as are delegated to them by schemes made by the Commission and approved by the Minister. ${ }^{86}$ As regards the gas industry, there are similar ministerial powers of control, stock known as British Gas Stock being issued by the Gas Council which is invested with the general duties of advising the Minister of Fuel and Power on questions affecting the gas industry and promoting the efficient exercise by the Gas Area Boards of their functions. The Area Boards are, however, the dominant bodies in this industry and each Board settles its own program of capital expenditure with the.Minister who consults the Gas Council before approving the program. Each Area Board notifies its stock requirements to the Gas Council which has power to issue the necessary stock provided that any expenditures on reorganization or development is in conformity with the general program settled by the Board with the Minister. ${ }^{87}$ As regards the iron and steel industry, the powers of control are exercised by the Minister of Supply over the Iron and Steel Corporation which is empowered to issue British Iron and Steel Stock and is responsible for securing a balance of revenue against outgoings in respect of its own functions as well as those of the publicly owned companies whose securities it holds. ${ }^{88}$ As regards the coal industry, the control powers are exercised by the Minister of Fuel and Power over the National Coal Board which is not however empowered to issue stock since the compensation stock for transferred assets in that case was government stock. ${ }^{89}$ Working capital however may be provided by advances by the Minister up to a limit of $\delta_{1} 15^{\circ}$ million for the quinquennium 1946 -195I and thereafter of

\footnotetext{
${ }^{83}$ First Annual Report of the British Electricity Autrority, 1947-1948 App. 40.

Bt Electricity Act, I947, $\$ 46$.

${ }^{80} I d . \S 5$.

${ }^{8 B}$ Iron and Steel Act, I949, pt. IV.

B5 Transport Act, I947, pt. VI.

${ }^{87}$ Gas Act, I948, pt. III.

${ }^{89}$ Coal Industry Nationalisation Act, 1946, \$21.
} 
such amount as Parliament may determine. ${ }^{00}$ Advances made by the Minister up to the end of $x 947$ totalled $f_{3} 33$ million and no further advances were made in 1948 , the capital expenditure being financed from the Board's own resources. ${ }^{91}$

D. Consideration of Matters Referred by Consumers' Councils

There has been set up in connection with most public corporations a series of advisory councils under various titles (such as consumers' councils or consultative councils) whose main duty is to ascertain the views of consumers or users of the goods or services provided and to make representations thereon either to the particular corporation or direct to the minister concerned. The members of these councils are appointed by the minister, after consultation with representative interests, as having adequate knowledge of the requirements of those interests and qualifications for exercising wide and impartial judgment on the matters referred to them either by the consumers or users or by the minister or the public corporation itself. The councils make annual reports to the minister who lays them before Parliament, where they can be discussed in the same way as the annual reports of the corporations themselves. Thus, for the coal industry, two consumers' councils are set up, one industrial and one domestic, and there is provision for regional councils which have so far not been appointed..$^{22}$ As regards electricity and gas, there is a consultative council for the area of every Area Board as well as local or district committees for each area. There is a link between the council and the Area Board since the chairman of the council is an ex officio member of the Board. ${ }^{93}$ For transport, there is a Central Transport Consultative Committee for Great Britain and Transport Users Consultative Committees for Scotland, Wales, and London; and the Minister of Transport has powers (not exercised so far) to set up similar committees for such areas as he may direct. ${ }^{94}$ For iron and steel, there are to be a Consumers' Council and also committees dealing with the interests of particular classes of consumers either as regards locality or products. ${ }^{95}$ As regards broadcasting, there are a regional advisory council in each region to deal with the program policy of the region and other advisory committees dealing with broadcasting services and business operations of the British Broadcasting Corporation. For civil aviation, an Air Transport Advisory Council has been set up in the form of an administrative tribunal under a legal chairman, and committees also function for particular areas. ${ }^{96}$

The consultative council in the case of electricity reports its findings to the Area Board and may, after consultation with the Area Board, make representations to the Central Electricity Authority and further, after consultation with the Central Authority, to the Minister of Fuel and Power. Any defect in the general plans

\footnotetext{
${ }^{\circ 0} \mathrm{Id}$. $\$ 26$.

91 Annual Report of the National Coll Board 133 (1948).

${ }^{22}$ Coal Industry Nationalisation Act, I946, $\$ 4$.

${ }^{23}$ Electricity Act, 1947, \$7, and Gas Act, 1948, \$9.

is Transport Act, 1947, $\$ 6$.

${ }^{96}$ Civil Aviation Act, 1949, 9 \& Io GEo. 6, c. 70, §12.

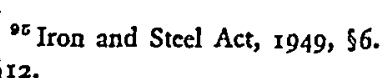


and arrangements of the Area Board can be remedied by the Minister by means of a notice to the Central Authority which in turn gives the necessary direction to the Area Board. In the case of gas, the consultative council may make representations to the Minister after consultation with the Area Board but without reference to the Gas Council. The Minister can refer any question for inquiry and report to a person appointed by him after consultation with the Lord Chancellor. After consideration of the report, the Minister can give any necessary directions to the Area Board, at the same time sending a copy thereof to the Gas Council. In the case of both electricity and gas, district committees of consultative councils are usually set up. The press is generally admitted to meetings of the council and some councils admit the public to their meetings. The consultative councils deal with consumers' complaints about service or quality and also participate in the formulation of policy and planning. 'They thus have wider powers than the coal consumers' councils which deal only with complaints and then only if the National Coal Board fails to give satisfaction and some question of principle, such as unfair treatment, is involved. ${ }^{97}$ No regional consultative councils have been appointed for the coal industry, as neither the Domestic nor the Industrial Coal Consumers' Council favors such appointments. The coal consumers' councils do not admit the press or the public to their meetings. In the case of transport, the Central Transport Consultative Committee (which can deal with services provided and charges therefor) has made its annual report to the Minister of Transport which mentions various recommendations made by the Committee to the British Transport Commission on such matters as the extension of mechanical handling of goods, the improvement of road transport facilities at docks, and the need for car parking facilities at dormitory stations. ${ }^{98}$

The reason for setting up these consumers' councils is that, since public corporations are invested to a large extent with monopoly powers, special machinery is necessary to enable consumers to air their grievances and, where they are unable to secure redress from the corporations themselves, to bring their complaint ultimately to the notice of the responsible minister himself. The machinery established is, as indicated above, somewhat complex and provides in the last resort for action by the minister in the form of directions to the corporation concerned to introduce remedial measures removing the cause of complaint. As yet the consumers' councils are in an early stage of development and, having set up their organization with the assistance of local committees, they have been active in securing publicity for their work, and establishing liaison with the corporations, on the one hand, and with representative groups of consumers' organizations, on the other. So far there is no evidence of specific direction by the ministers, the ultimate remedy provided by the regulating statutes. The councils for the electricity industry have issued two sets of annual

${ }^{97}$ See Griffith, The Voice of the Consumer, 2I Por. Q. I7I (1950); Grove, The Consumer Councils for Gas and Electricity, 28 Púb. ADM. 221 (I950).

${ }^{93}$ Annual Report of the Central. Transport Consultative Committee for Year Ended Dec. 3 r, 194933 (London, I950). 
reports and, though they acknowledge some assistance given by press publicity and local poster advertising, they still feel that something more vital is necessary to make consumers realize that the councils have been established independently of the corporations for the express protection of the consumers. ${ }^{99} \mathrm{~A}$ technique has been established whereby Area Electricity Boards have given required information to the councils and arranged for them to inspect the work of generation as well as supply. Where complaints have been made to the Area Boards, they have frequently been settled to the satisfaction of the parties concerned or explanations have been forthcoming as to why (e.g., owing to cuts in the capital investment program) an immediate solution is not possible. Few councils have found it necessary to refer to the Central Electricity Authority any representation on which conclusions have been referred to the Area Board. ${ }^{100}$

It must therefore be concluded that the powers of ministerial control arising as a result of representations from consumers' councils are more in the nature of an ultimate safety-valve which is available on rare occasions, and it is not to be expected that they will be exercised with any frequency.

III

Judictal Control

A. The Constitutional and Legal Status of Public Corporations

The classical division of governmental powers in the British constitution is among three main organs, viz., the legislature, the executive, and the judiciary. ${ }^{101}$ The functions of the executive are exercised through the medium of the government departments and by statutory conferment of specified powers upon local authorities. The public corporations seem to have established their constitutional position as organs of the executive somewhere between the government departments and the local authorities.

On the one hand it has been definitely settled by the Court of Appeal in Tamlin v. Hannafor $d^{102}$ that a public commercial corporation does not rank as a government department enjoying Crown privileges and being fully responsible to the departmental minister concerned. It is thus distinguishable from the General Post Office which is fully controlled by a minister of the Crown (viz., the Postmaster-General). The question in issue in that case was whether a house owned by the British Transport Commission was Crown property exempt from the provisions of the Rent Restriction Acts. The Court decided that it was not so exempt. In the course of the judgment delivered by Denning, L. J., the following explanation of the status of the Commis-

\footnotetext{
${ }^{90}$ See, for instance, the reports of the South Eastern and Yorkshire Electricity Consultative Councils for r949-1950.

${ }^{100}$ As an exception, sec the report of the South East Scotland Electricity Consultative Committec for 1949-1950, which referred to the Central Electricity Authority the question of the disposal of the general reserve funds in its area.

101 "The age-long triple classification of governmental functions." E. C. S. WADE, ConstitutnonaL Law 210 (London, $4^{\text {th }}$ ed. I950).

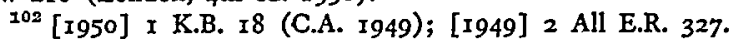


sion was given. The Transport Act, $x_{947}$, brings into being the British Transport Commission, which is a statutory corporation of a kind comparatively new to English law. It has many of the qualities which belong to corporations of other kinds. It has defined powers which it cannot exceed and it is directed by a group of men whose duty it is to see that those powers are properly used. It may own property, carry on business, borrow and lend money, just as any other corporation may do, so long as it keeps within the bounds which Parliament has set, but the significant difference in this corporation is that there are no shareholders to subscribe the capital or to have any voice in its affairs. The money which the corporation needs is raised, not by the issue of shares, but by borrowing, and its borrowing is not secured by debentures but is guaranteed by the Treasury. If it cannot repay, the loss falls on the Consolidated Fund of the United Kingdom, that is to say, on the taxpayer. There are no shareholders to elect the directors or to fix their remuneration. There are no profits to be made or distributed. The duty of the corporation is to make revenue and expenditure balance taking one year with another but not to make profits. If it should incur losses and be unable to pay its debts, its property is liable to execution, but it is not liable to be wound up at the suit of any creditor. The taxpayer would, no doubt, be expected to come to its rescue before the creditors stepped in. Indeed, the taxpayer is the universal guarantor of the corporation. But for him it could not have acquired its business at all nor could it continue for a single day. It is his guarantee that has rendered shares, debentures, and such like unnecessary. $\mathrm{He}$ is clearly entitled to have his interests protected against extravagance or mismanagement.

There are other persons who also have a vital interest in its affairs. All those who use the services which it provides and all whose supplies depend on it are concerned in seeing that it is properly run. The protection of the interests of all these persons -taxpayer, user, and beneficiary-is entrusted by Parliament to the Minister of Transport. $\mathrm{He}$ is given powers over this corporation which are as great as those possessed by a man who holds all the shares in a private company, subject however to a duty to account to Parliament for his stewardship. It is the Minister who appoints the members of the Commission and fixes their remuneration. They must give him any information he wants and, lest they should not prove amenable to his suggestions as to the policy they should adopt, he has power to give them directions of a general nature in matters which appear to him to affect the national interest (as to which he is the sole judge) and they are then bound to obey. These are great powers but still the corporation cannot be considered as his agent, any more than a company is the agent of the shareholders or even of a sole shareholder. In the eye of the law the corporation is its own master and is answerable as fully as any other person or corporation. It is not the Crown and has none of the immunities or privileges of the Crown. Its servants are not civil servants and its property is not Crown property. It is as much bound by acts of Parliament as any 
other subject of the King. It is a public authority and its purposes are public purposes but it is not a government department nor do its powers fall within the province of government.

On the other hand, the public corporation is more closely linked with the responsible minister than are local authorities. The latter are controlled by their council of elected members and they exercise autonomy within the limits of their statutory powers. Their relations with the government departments, though entailing a certain amount of control in specified matters including financial control in the matter of exchequer grants, are more distant than those of the public corporations, to which the minister can give directions on a variety of matters relating to the national interest as well as on all capital development programs.

The new constitutional position of the public business corporation is slowly receiving recognition partly as the result of parliamentary debate and partly as the result of discussion in legal treatises and periodicals. ${ }^{103}$ It is to be expected that the courts would in suitable cases (though they are likely to be extremely rare) allow the prerogative orders of mandamus or prohibition, and perhaps even certiorari, to issue against a public corporation as they have done in the past as regards public utility undertakers, so that a corporation could be ordered to carry out a particular duty where no other legal remedy was available or to refrain from a particular act of a judicial nature which was in excess of its powers. ${ }^{104}$ In the case of an order of certiorari, the decision of the corporation might well be reviewed in so far as it imposed a particular liability or sought to determine the rights or property of particular persons. ${ }^{105}$

\section{B. Subjection of Corporations to the General Law}

Standard provisions in the creating statutes usually set up the public corporation as a body corporate, with perpetual succession and a common seal and power to hold land without license in mortmain. This applies alike to the central corporations and their subsidiaries in the various industries, e.g., the British Transport Commission and its six Executives or the Central Electricity Authority and the Area Boards. Having vested the corporation with its legal status as a corporation, the creating statute generally declares that nothing in its provisions is to be deemed to exempt the corporation from liability for any tax, duty, rate, levy, or other charge whatsoever, whether general or local. ${ }^{106}$ Further, having conferred specific powers on the corporation, the creating statute usually declares that those powers relate only to the capacity of the corporation as a statutory corporation and that they are not to

${ }^{103}$ See WADE, op. cit. supra note IOI; Friedmann, The New Public Corporations and the Las, I0 Mod. L. Rev. 233, 377 (I947); Public ENTERPRIse (Robson ed. 1937).

${ }^{104}$ As to prohibition, see The King v. Electricity Commissioners; Ex parte London Electricity Joint Committee Co., [1924] I K.B. I7I (C.A.), where the Commissioners were restrained from holding a public inquiry because the scheme of electricity supply to be presented at the inquiry was ultra vires as threatening an infringement of the rights of private electricity companies.

${ }^{105}$ Local Government Board v. Arlidge, [1915] A.C. 120.

${ }^{100}$ Coal Industry Nationalisation Act, 1946, \$47; Electricity Act, I947, \$I I. 
be construed as authorizing the disregard by the corporation of any enactment or rule of law. Where the corporation is not, however, subject to the general law on any particular topic, express provision is necessary to establish its exceptional position. Thus special provisions were included in Part $\mathrm{V}$ of the Local Government Act, I $9488^{107}$ to exempt railway, canal, and electricity hereditaments from the general liability for the payment of rates and to enable the corporations concerned, viz., the British Transport Commission and the British Electricity Authority, to make payments to rating authorities in lieu of rates which would ordinarily have been payable in respect of the hereditaments concerned.

On the creation of a public corporation, the statutory provisions for the vesting in the corporation of the assets of the transferred undertakings usually provide that the property, rights, liabilities, and obligations of the former undertakers are to vest on the vesting date in the corporation or, where there is a two-tier organization with a central authority and subsidiary area authorities, in such of the authorities as may be designated by ministerial order. ${ }^{108}$ Thus the new corporation is substituted for the former undertakers in agreements made before the vesting date except in so far as they are impossible of performance. The new corporation also usually acquires a limited right of disclaiming agreements and leases made within a short period (about two years) before the vesting date where they were not reasonably necessary or were made with an unreasonable lack of prudence. ${ }^{109}$

The creating statute also generally provides that the statutory enactments (including statutes, regulations, and orders) previously applicable to the transferred industry are to apply to the new corporation subject to the adaptations and modifications scheduled to the creating statute. This includes local enactments relating to the industry except in so far as they are inconsistent with or rendered redundant by the operation of the creating statute. Where necessary also the minister is empowered to repeal or amend, by order, any local enactment which is no longer applicable. ${ }^{110}$

\section{Limitation of Actions}

Although the public corporations are frequently designated in the creating statutes as public authorities, ${ }^{111}$ they are not entitled to the full privileges of the Public Authorities Protection Act, $1893,{ }^{112}$ and Section 2I of the Limitation Act, 1939, ${ }^{113}$ which prevent legal proceedings (whether actions or prosecutions) being brought against public authorities except within the limit of one year from the date of the accrual of the cause of action, if the proceedings are in respect of any act,

107 II \& 12 GEO. 6, c. 26.

${ }^{108}$ Sce, for cxample, Electricity Act, I947, \$I4; Gas Act, I948, §I7; and Transport Act, 1947, §r4.

${ }^{100}$ See Electricity Act, 1947, \$18; Gas Act, 1948, \$22; Transport Act, 1947, \$15.

110 Sec Electricity Act, I947, $\$ 57$; Gas Act, I948, $\$ 56$.

${ }^{111}$ E.g., the British Transport Commission and its executives, under $\$ \S \Sigma$ and 5 of the Transport Act, 1947; the Iron and Steel Corporation under $\$ 1$ of the Iron and Steel Act, I949.

${ }^{113} 56$ \& 57 VICT., c. 6r.

$1132 \& 3$ GEO. 6, c. 21 . 
neglect, or default of a servant or agent of the authority. They are, however, granted a modified privilege in that respect in as much as the limitation period of six years which, under Sections 2 and 3 of the Limitation Act, I939, applies generally as regards actions for contract and tort and certain other actions is shortened to three years so far as they are concerned. ${ }^{114}$ It should be remembered, however, that a committee which sat recently under the chairmanship of Mr. Justice (now Lord Justice) Tucker recommended the abolition of the special periods of limitation of actions in respect of public authorities and the new public corporations. ${ }^{115}$

\section{Special Tribunal for Transport Charges}

The establishment of a special tribunal known as the Transport Tribunal ${ }^{110}$ was due in part to the need of a tribunal to undertake duties formerly allotted to two statutory tribunals, viz., the Railway Rates Tribunal and the Railway and Canal Commission set up under the Railways Act, $\mathbf{I} 92{ }^{117}$ and the Railway and Canal Traffic Act, I888, ${ }^{118}$ respectively. In addition, the Tribunal became responsible for determining the charges to be made by the British Transport Commission for the services provided by the Commission as well as the terms and conditions applicable to the provision of those services, including terms and conditions as to the liability of the Commission for loss or damage. ${ }^{110}$ The Tribunal is empowered to adjudicate on schemes of charges submitted to it by the Commission after hearing objections at a public inquiry from representative bodies of users of the services or providers of comparable services. The decision of the Tribunal takes the form of a confirmation of the scheme examined with or without modifications or of a refusal to confirm it. The Tribunal has in addition power to alter a charges scheme on the application of the Commission or representative bodies of persons concerned as well as to review the operation of a charges scheme at the instigation of the Minister of Transport. Overriding provisions prevent the Commission and the Minister from taking any action in respect of charges schemes in such a way as to prevent the Commission from discharging its general duty to balance outgoings against revenue or from giving effect to ministerial directions duly given under the Act of 1947 .

As regards constitution and procedure, the Transport Tribunal inherits the powers conferred on the Railway Rates Tribunal which it displaces. Those powers are contained in The Railways Act, rg2I, which has been slightly modified to meet the new position. The Transport Tribunal consists of three permanent members to which the Minister of Transport may add two additional members chosen from panels of persons possessing knowledge of (a) general trading, labor, and agricultural interests, and (b) transport interests. In the exercise of its functions, the Tribunal

\footnotetext{
114 Coal Industry Nationalisation Act, I946, §49; Transport Act, 1947, \$11; Electricity Act, 1947, \$12; Gas Act, $1948, \S x_{4}$; Iron and Steel Act, 1949, \$10.

${ }^{115}$ Report dated June 30, 1949: CMD. No. 7740.

${ }^{118}$ Under the Transport Act, r947, pt. V.

117 II \& 12 GEo. 5, c. $55 .{ }_{118}^{51}$ \& 52 VICT., c. 25.

110 Transport Act, 1947, $\$ 76$.
} 
has the general powers of the High Court in England (and the Court of Session in Scotland), including such powers as relate to the attendance and examination of witnesses, the production and inspection of documents, the enforcement of orders, and the entry on and inspection of property. ${ }^{120}$ Appeals from the Tribunal on questions of law lie to the Court of Appeal in England (and to the Court of Session in Scotland). The Tribunal is under obligation to make an annual report of proceedings to the Minister of Transport.

Under transitional provisions ${ }^{121}$ the Minister of Transport has power to make regulations authorizing the Commission to levy additional charges with a view to securing sufficient revenues but before so doing he is under obligation to consult with and consider the advice of the permanent members of the Tribunal acting as a consultative committee. Such consultation was effected in connection with a recent application by the Commission for an increase of $16 \% \frac{2}{3}$ per cent in railway and canal charges and certain increases in dock charges. After a public inquiry extending over several days when representatives from various bodies interested were heard, the committee advised that the additional charges should be made. ${ }^{122}$

A draft scheme under the title of the London Area (Interim) Passenger Charges Scheme was submitted to the Transport Tribunal under section 76 of the Transport Act, I947, and, after holding a public inquiry thereon, the Tribunal issued its judgment on August 23, 1950.123 The main objectives of the scheme were to secure greater equality of fares for different journeys of similar length and for journeys between common points by alternative routes, and in particular to remove the disparities between the charges of the Railway Executive (responsible for the main line suburban railways) and those of the London Transport Executive (responsible for the coordinated system of transport by rail, bus, trolley-bus, and tram originally set up for the London Passenger Transport Area), the former charges being usually higher than the latter. Further objectives were to encourage the most convenient use by the public as a whole of the passenger transport facilities in London and to rationalize the anomalous system of early-morning workmen's fares which were available for some passengers but not others. The scheme was estimated to yield $f_{3}, 691,000$ or 4.87 per cent more gross receipts than the charges in force and included an increased charge for workmen's tickets on railways, trolley-buses, and trams and an extension of the system to ordinary buses, a new day return fare for suburban lines on British Railways, a standard charge for season tickets on London Transport lines and suburban lines of British Railways, an increase in the scale of bus fares, and a reduction in the mileage rate for London Transport coach fares. The Tribunal considered that the scheme would yield in a normal year approxi-

\footnotetext{
${ }^{120}$ Id., Tenth Schedule; Transport Tribunal Rules, 1949 (S. I. No. 989).

131 Transport Act, 1947, \$82.

${ }^{123}$ See reports dated Feb. 6 and $16,1950$.

${ }^{123}$ Report issued by H. M. Stat. O. $\left(88-83^{-I^{*}}\right)$.
} 
mately $f_{\mathrm{I}}$ million more than the contribution which the London Area ought to be called on to make to the total financial requirements of the British Transport Commission and accordingly requested the Commission to effect a reduction. This the Commission did mainly by amendments of the early-morning return railway fares and the retention of cheap fares for shift workers on railways, trams, and trolley-buses. The scheme as settled was estimated to yield $£_{2}, 680,000$ or 3.53 per cent more gross receipts than the charges in force.

\section{E. Arbitration Tribunals}

In order to deal with the various questions arising in connection with the transfer of assets, rights, and liabilities from private owners or local authority undertakers to the public corporations, special arbitration tribunals are established by the various creating statutes except as regards coal, where the questions are determined by an arbitrator chosen from a panel of arbitrators appointed by the Lord Chancellor. ${ }^{124}$ Thus in the case of electricity, ${ }^{125}$ the arbitration tribunal consists of three members appointed by the Lord Chancellor, one with legal experience to act as president and two others with experience in business and finance. ${ }^{126}$ The tribunal is a court of record and its orders are enforceable in England and Wales as orders of the High Court. It has power to administer oaths, correct mistakes in awards, examine witnesses, and impose costs in accordance with the provisions of the Arbitration Act, 1950. Appeals lie from the tribunal on questions of law (and on certain limited questions of fact) to the Court of Appeal. The minister concerned has the right to be heard in all proceedings before the tribunal and appeals therefrom. The tribunal makes its own rules of procedure subject to the approval of the Lord Chancellor. The remuneration of the members of the tribunal and its officers is paid by the minister who is reimbursed by the British Electricity Authority. The matters dealt with by the tribunal relate to such matters as the compensation to be paid to holders of transferred securities if the minister and the stockholders' representative fail to agree on the matter, the disclaimer by the corporation of agreements and leases made unreasonably or imprudently by the owners of the undertakings transferred, the dissipation of assets by companies prior to transfer, or the payment of excessive dividends or interest by directors of companies prior to transfer. Similar provisions are enacted in the case of gas, transport, and iron and steel. ${ }^{127}$ Since these tribunals are mainly concerned with the settlement of the problems and disputes arising out of the transfer of assets from private to public ownership, their importance diminishes with the passage of time and they do not affect the permanent structure of the corporation.

\footnotetext{
124 Coal Industry Nationalisation Act, 1946, \$6r.

${ }^{125}$ Electricity Act, $1947, \$ \$ 3 \mathrm{r}-33$.

${ }^{128}$ As regards Scottish procedure, the legal member is appointed by the Lord President of the Court

${ }^{127}$ Gas Act, 1948, \$\$63-66; Transport Act, 1947, \$\$r05-I07; Iron and Steel Act, 1949, \$\$43-46.
} of Session. 


\section{F. Ultra Vires Control}

Public corporations created by statute are entitled to exercise the powers mentioned in the statute and these powers are usually expressed in comprehensive terms which confer upon the corporations ample scope for the exercise of their activities. This follows the analogy of modern memoranda of association of companies which allow a wide range of operation for the companies. In some cases, the statute limits the powers of the corporation by special restrictions, e.g., a prohibition on certain forms of manufacture which the government has decided to leave within the sphere of private enterprise. Where there are ancillary corporations (as in the case of the Transport Executives), the powers of the corporations are not set out completely in the creating statute but need to be extracted partly from instruments of delegation made by the dominant central corporation.

If a public corporation acts in excess of its powers, or if it misuses the powers entrusted to it, a person aggrieved can approach the courts for a judicial decision on the matter, and the courts can pronounce the act to be ultra vires of the corporation and therefore entitling the complainant to a legal remedy. Where the person aggrieved is himself resisting legal action by the corporation, he can raise a similar issue in defence of his case before the courts. ${ }^{128}$ The remedy sought is usually a declaration by the court that the corporation's act is ultra vires or an injunction restraining the corporation from further exercise of the power in dispute. In determining the scope of the corporation's powers, the court will have regard to the express terms of the creating statute (and any necessary instrument made thereunder) and to anything which is necessarily and properly required for carrying into effect the purposes of incorporation or which may be fairly regarded as incidental to or consequential upon what the legislature has authorized. ${ }^{129}$

Where the corporation is acting under its general statutory powers, cases of ultra vires will probably be of infrequent occurrence in view of the wide range of those powers, especially where they extend (as in the case of the National Coal Board or the Electricity Boards) ${ }^{130}$ to such activities as are requisite, advantageous or convenient for the discharge of its express duties or are incidental or conducive thereto. Where the corporation is subject to special restrictions (e.g., as to powers of manufacture), private traders will no doubt be alert to challenge acts of the corporation which exceed those restrictions. The corporation can, however, forestall any such challenge by securing further statutory powers when contemplating new operations. Thus the National Coal Board has been empowered by section 2 of the Coal Industry Act, x949, to extend the area of its activities outside Great Britain subject to orders made by the Minister of Fuel and Power, and under the National Coal Board (Overseas Activities) Order, 1949, as amended in $1950,{ }^{131}$ the Board has

\footnotetext{
${ }^{228}$ See Friedmann, supra note 103, at 244 and 379.

2308 HaLSBURY'S LAWS OF ENGLAND 72 (2d ed. 1931).

${ }^{130}$ Coal Industry Nationalisation Act, 1946, \$1; Electricity Act, 1947, \$2(5).

${ }^{131}$ S. I. I949, No. 2292; S.I. 1950, Nos. I68I and I9rT.
} 
extended powers of selling carbonization products abroad, maintaining representatives abroad to promote the sale of coal, acquiring machinery abroad for use in Great Britain, and acquiring coal abroad and supplying it to any country.

The case of Smith v. London Transport Executive heard before the Court of Appeal ${ }^{132}$ raised the question of the scope of the powers to run omnibus services delegated to the London Transport Executive by the British Transport Commission. The appellant claimed an injunction restraining the Executive from running a competing line of omnibuses over a route extending 400 yards outside the London Passenger Transport Area without obtaining a road service license, or a declaration that such action by the Executive was ultra vires. The Court, after careful examination of the powers of the Commission under the Transport Act, 1947, and the powers delegated to the Executive by the instrument of delegation, found in favor of the Executive on the ground that the instrument of delegation empowered the Executive to carry on not only the activities of the former London Passenger Transport Board undertaking which had been transferred to the Commission but also the general activities of the Commission ${ }^{133}$ (viz., to carry passengers by road within Great Britain) so far as they were carried on in connection with the London Board activities or were ancillary thereto. In such cases the Executive was relieved ${ }^{134}$ of the obligation of obtaining a road service license. Had such an obligation been in force, the appellant would have had an opportunity of opposing the grant of the license by the licensing authority.

Examples of special restrictions are as follows. The Central Electricity Authority is not entitled to manufacture electrical plant or electrical fittings for export and an Area Electricity Board is not entitled to manufacture electrical plant or fittings or to sell, hire or supply electrical plant (as distinct from fittings). ${ }^{135}$ A Gas Area Board is not entitled to manufacture gas plant or gas fittings for export. ${ }^{136}$ The British Transport Commission is not authorized to engage in the building of ships over a gross tonnage of 175 tons or to manufacture things for other undertakers or to trade in spare parts for road vehicles. ${ }^{137}$

In another transport case ${ }^{138}$ decided by Mr. J. P. Eddy, K. C., the stipendiary magistrate of West Ham, the question arose as to the powers of the Railway Executive as agent of the British Transport Commission to administer bylaws made by a former railway company, whose undertaking had been transferred to the Commission by the Transport Act, I947. The point was raised in defence by a market employee prosecuted for obstruction with a barrow at a railway station under bylaws made by the London and North Eastern Railway Company. The magistrate's ruling

\footnotetext{
132 [I949] 2 All E.R. 295 (C.A.).

${ }^{133}$ I.e., under $\$ 2(x)$ of the Transport Act, 1947.

134 By $\$ 65(I)$ of the Transport Act, 1947 .

${ }^{135}$ Electricity Act, 1947, $\$ 2$.

${ }^{138}$ Gas Act, 1948, \$1.

137 Transport Act, 1947, \$2.

${ }^{138}$ Reported in Daily Telegraph, Oct. 3, 1950.
} 
was that under Section I4(2) of the Act of 1947 the Commission (and the Executive as agent of the Commission) had, on the transfer of the railway undertaking, all the rights which the railway company had including rights conferred by bylaws made by the railway company.

Another case, National Coal Board v. Hornby and Others, ${ }^{139}$ heard in the Chancery Division of the High Court, raised the question whether the option to purchase a farm granted to a colliery concern by the owner was exercisable by the National Coal Board on the transfer of the assets of the colliery concern to the Board under the Coal Industry Nationalisation Act, r946. The Court held in favor of the Board on the ground that the assets (including the option) of the colliery concern passed to the Board under Section 5(I) of the Act of 1946 as land available for coal industry activities within the meaning of Paragraph 9 of Part I of the first Schedule to the Act, and the Board was entitled to exercise the option under the original deed. The fact that the Board, under an alternative provision contained in Section 7 and the second Schedule of the Act, could have acquired the farm on giving notice of acquisition to the owner but had failed to serve the requisite notice did not prevent the Board from relying entirely on the former provision. The Court therefore decreed specific performance of the contract of purchase which, under the terms of the deed, arose on the service of notice to exercise the option to purchase.

${ }^{130}$ [1949] 2 All E.R. 615 (Ch. D.). 